NBER WORKING PAPER SERIES

ARE DEVALUATIONS CONTRACTIONARY?

Sebastian Edwards

Working Paper No. 1676

NATIONAL BUREAU OF ECONOMIC RESEARCH

1050 Massachusetts Avenue

Cambridge, MA 02138

August 1985

I have benefitted from discussions with Sweder van Wijnbergen. All errors, however, are my own. Financial support from the National Science Foundation, Grant SES 84-19932, is gratefully acknowledged. The research reported here is part of the NBER's research program in International Studies. Any opinions expressed are those of the author and not those of the National Bureau of Economic Research. 
NBER Working Paper \#1676

August 1985

\section{Are Devaluations Contractionary?}

\section{$\underline{\text { ABSTRACT }}$}

Recently a number of authors have criticized the role of devaluations in traditional stabilization programs. It has been argued that, contrary to the traditional view, devaluations are contractionary, and generate a decline in aggregate output. In spite of the renewed theoretical interest in the possible contractionary effects of devaluations, the empirical evidence on the subject has been quite sketchy. In this paper the Khan and Knight (1981) model is extended to empirically address the issue of contractionary devaluations. The extended model considers the effect of money surprises, fiscal factors, terms of trade changes and devaluations on the level of real output. The results obtained, using a variance components procedure on data for 12 developing countries, provide some support to the short-run contractionary devaluation hypothesis; the results obtained indicate that in the short run a devaluation will generate a decline in aggregate output. It is also found that after one year a devaluation will have an expansionary effect on output. The evidence suggests that in the long run, devaluations will have no effect on output.

Sebastian Edwards Department of Economics University of California, Los Angeles Los Angeles, CA 90024 
CPDTA/disk SE5/doc. se4/draft/7-9-85

\section{Introduction}

Devaluations are usually an important component of orthodox stabilization programs. 1/ According to the traditional theory it is expected that a devaluation will result in expenditure switching, increased production of tradables, higher exports, and in an improvement of the external position of the country in question. 2/ Recently, however, traditional stabilization packages, and especially their devaluation component, have come under attack by a number of authors. Even though some of the reservations regarding the role of devaluations as a stabilization policy tool are not new -- and date back, at least, to the elasticity pessimism controversy -- they have encountered new acceptance among some economists and policymakers. $\underline{3}$ '

The main thrust of this new critique to devaluation has been subsumed under the term contractionary devaluation. There are several theoretical reasons why, contrary to the traditional view, a devaluation can be contractionary, and generate a decline in real activity. First, a devaluation will result in a higher price level, generating a negative real balance (or Pigou) effect. This, in turn, will result in lower aggregate demand and output. $4 /$ Second, a devaluation can generate a redistribution of income from groups with a low marginal propensity to save to groups with a high marginal propensity to save, resulting in a decline in aggregate demand and output. (See, for example, Diaz-Alejandro, 1965. See also Krugman and Taylor, 1978.) Third, if the price elasticities of imports and exports are sufficiently low, the trade balance expressed in domestic currency may worsen, generating a recessionary effect. And fourth, in addition to these demand-related effects, there are a 
number of supply-side channels through which devaluations can be contractionary. For example, van Wijnbergen (1985) has recently developed a model with intermediate goods and informal (curb) financlal markets where under certain conditions a devaluation can result in an upward (recessionary) shift of the aggregate supply. 5/

In spite of the renewed theoretical interest on the possible contractionary effects of devaluations, the empirical analysis has been somewhat sketchy. Gylfason and Schmidt (1983), for example, have constructed a small macro model with intermediate goods, where devaluations have two conflicting effects: On one hand they generate an expansion through aggregate demand; on the other hand, a devaluation results, through its effect on the cost of imported intermediate inputs, in an upward shift in the aggregate supply schedule. They then establish the conditions required for the contractionary effect to dominate. The implications of the model are analyzed by imputing plausible values to the corresponding parameters for a group of five developed countries and five developing countries. With the exceptions of the U.K. and Brazil these results suggest that, as postulated by the traditional theory, devaluations have a positive effect on aggregate output. Connolly (1983) considered a group of 22 countries and regressed the change in the rate of real growth on the change in the nominal exchange rate. The coefficient obtained was positive and marginally significant, providing some sipport to the hypothesis of expansionary devaluations. However, as Connolly himself acknowledges, his results are subject to a selectivity bias, since typically countries that devalue do so after having entered into a recession. Gylfason and Risager (1984) developed a model for a small country, which stresses the effects of devaluations on interest payments 
on the foreign debt. Using imputed parameter data Gylfason and Risager suggest that while devaluations are generally expansionary in developed countries, in developing countries they are likely to be contractionary. Other authors have constructed country-specific simulation models to analyze, among other things, the effectiveness of devaluations as stabilization policy tools. Branson (1985), for example, has recently constructed a small simulation model for Kenya to investigate these issues. His results suggest that, contrary to the traditional view, a devaluation will have important contractionary effects in the Kenyan economy. Lance Taylor and Jeffrey Rosensweig (1984), on the other hand, built a fairly large computable general equilibrium model for Thailand, and simulated the effects of a number of policy measures, including a devaluation, on the Thai economy. Their results suggest that a devaluation of the baht of 10 percent will have an expansionary effect and will generate an increase in real GDP of 3.3 percent. Other studies have discussed the output effects of devaluations in a less formal way. Cooper (1971a), in his well-known study, analyzed 24 devaluations that took place between 1953 and 1966. After looking at the benavior of the principal components of aggregate demand he concluded that "devaluation itself often initially tends to depress economic activity in the devaluing country, contrary to what has normally been expected" (p. 504). Krueger (1978) analyzed output behavior during the periods surrounding major devaluation episodes in the countries considered in the NBER project on trade liberalization. She found that in most cases devaluations had been associated with expansions in the level of real activity. 6/ Edwards (1985) investigated the effects of 30 major devaluations in 22 developing countries. He found that in only 4 out of the 30 cases the level of real GDP declined after the 
devaluation. However, when rates of growth of real GDP were considered, a slightly different picture emerged; it was found that in the period immediately following the devaluation the rate of real growth dropped in 10 out of 30 cases. In sum, then, the existing evidence regarding the effect of devaluations on real economic activity is mixed; while some studies suggest that devaluations have an expansionary effect, others indicate that they generate a contraction in the economy.

Most studies that have investigated the effects of devaluations on economic activity suffer from at least one of the two following shortcomings: First, they use a "before" and "after" approach where they compare the performance of the economy around the devaluation period, without taking into account the behavior of other variables like monetary policy, fiscal policy, and external disturbances. Second, in order to investigate the effects of devaluations on growth and output, they perform "indirect" tests, using simulation models with imputed parameter values obtained from other studies. The purpose of the present paper is to empirically analyze the contractionary devaluation issue using a procedure that is not subject to the above mentioned criticisms. In particular, in this paper the approach taken by Khan and Knight (1981) is extended to investigate the effect of devaluations on real output growth. The paper is organized in the following form. In Section II the model being tested is briefly presented. In Section II the results obtained using annual data on 12 developing countries for 1965-80 are reported and discussed. Finally, in Section IV the main points of the paper are summarized and some directions for future research are suggested. 


\section{The Model}

In their recent analysis of the effects of stabilization programs on aggregate production in developing countries Khan and Knight (1981) argued that the level of economic activity in these countries will be affected by a number of variables, including the existing disequilibrium in the money market, and the level of fiscal expenditure. In the present paper, the Khan and Knight (1981) formulation is modified in various respects. First, in accordance with the recent rational expectations literature their excess money supply term is replaced by a money surprise or unexpected money growth term. If Second, the possible role of terms of trade changes on the level of activity are explicitly incorporated into the picture. And third, an exchange rate term is added into the regression analysis to explicitly investigate the effect of devaluations on real aggregate output.

An essential element in the traditional view of devaluations is the assumption that nominal devaluations generate an improvement in the domestic relative price of tradables to nontradables. That is, it is assumed that nominal devaluations result in real devaluations. It is indeed this relative price change that, according to this view, generates the process of expenditure-switching, balance-of-payments improvement and economic expansion. In this paper this assumption is not challenged and, as some of the existing evidence suggests, it is assumed that this is indeed the case. 8/ Consequently, the exchange rate term incorporated into the real output, reduced-form equation is a real exchange rate index. $9 /$

The modified, reduced-form equation for real output considered in this paper is: 


$$
\begin{aligned}
\log y_{t}=\alpha+\gamma_{1} t \text { ime } & +B_{1} \log (G E / Y)_{t}+B_{2}\left[\Delta \log M-\Delta \log M^{e}\right]_{t} \\
& +B_{3} \log \tau_{t}+B_{4} \log e_{t}+\varepsilon_{t}
\end{aligned}
$$

where $y$ is aggregate real output. Parameter $Y$ captures the trend rate of growth of real output; $(G E / Y)$ is the ratio of government expenditure to nominal income; $\Delta \log M$ is the actual rate of growth of nominal money, $\Delta \log M^{e}$ is the expected rate of growth of nominal money, and it is assumed that expectations are formed rationally and conditional on all available information. $\left[\Delta \log M-\Delta \log M^{e}\right]$, then, is the unexpected rate of growth of money. On the other hand, $\tau$ is the terms of trade, defined as the ratio of export prices to import prices. e is the real exchange rate defined as the relative price of tradables to nontradables. $10 /$ An increase in e, then, represents a real devaluation. Finally $\varepsilon$ is an error term. Equation (1) can in fact be considered as an open economy extension of the equation estimated by Barro (1978) in his influential paper on the role of monetary policy in the U.S.

In the estimation of (1) it is expected that $\beta_{q}>0$. To the extent that the rational expectations approach is correct $B_{2}$ will also be positive. The terms of trade coefficient $\left(\beta_{3}\right)$ is also expected to be positive. 11 / The $\beta_{4}$ coefficient captures the effect of (real) devaluations on real output growth and is the primary interest of this study. If devaluations are contractionary, as suggested by the neo-structuralist critique, $\beta_{4}$ will be significantly negative, indicating that, with other things given, a (real) devaluation will result in a decline in aggregate real. output. On the other hand 1f, as indicated by the more traditional approach, devaluations are expansionary the estimated value of $\beta_{4}$ would be positive. It should be noted, 
however, that since this is a reduced-form equation the $\beta_{4}$ coefficient will be picking up the total effect of devaluations on growth, without allowing us to establish whether there are indeed conflicting forces (i.e., contractionary and expansionary) as suggested by some models.

In equation (1) only contemporaneous values of the independent variables have been included. In the estimation, however, and in order to analyze whether there are differences between short-and long-term effects, lagged values were also introduced. For the case of the real exchange rate the inclusion of lagged values is important since some authors have argued that the contractionary effects of devaluations will be a short-run phenomenon [i.e., Cooper (1971a)].

III. Results

Equation (1) was estimated using a variance-components procedure on data for 12 developing countries for 1965-80. The countries included are: India, Malaysia, Philippines, Sri Lanka, Thailand, Greece, Israel, Brazil, Colombia, El Salvador, South Africa and Yugoslavia. These countries were chosen because of data availability: They were the only developing countries that had long enough time series for all the variables of interest. All of these countries have experienced important real exchange rate changes (i.e., real devaluations and appreciations) during the period under consideration, and all but El Salvador had also gone through episodes of major nominal devaluations. For the exact definition and sources of the data, see the Appendix.

Before estimating the real output equation (1) it is necessary to find adequate time series for the money surprises term [ $\Delta \log M-\Delta \log \mathrm{M}^{\mathrm{e}}$ ]. 
In this paper, as in a number of other studies on the subject, this unexpected money growth term was constructed, for each individual country, as the difference between actual money growth and the estimated rate of growth of money obtained from a money creation equation. 12/ In principle, the equation used to generate the expected rate of growth of money should include variables that indeed convey information to the different economic agents about the central bank behavior. In a number of developing countries money creation is an important source of fiscal deficit financing [Edwards (1983)]. For this reason, in the money creation equations used in this study the ratio of the fiscal deficit to lagged high-powered money was used as an explanatory variable. Additionally lagged values of $\Delta \log M$ were also included in this equation.

For each individual country, then, the following money creation equation was estimated:

$$
\Delta \log M_{t}=a_{0}+a_{1} \Delta \log M_{t-1}+a_{2} \Delta \log M_{t-2}+a_{0} \Delta \log M_{t-3}+a_{4} D E H_{t}+\mu_{t}
$$

where $M_{t}$ is broadly defined (M2) nominal money, $D E H_{t}$ is the fiscal deficit term and $\mu_{t}$ is a white noise term. The results obtained from the estimation of (2) for the twelve countries considered in this study for 1963-80 are reported in Table 1. As can be seen in all cases the fits are quite good. In ten of the twelve cases the coefficients of the fiscal deficit term $D E H_{t}$ are positive as expected. However, in only four cases -- Greece, Israel, Brazil and Colombia -- this coefficient is significant at conventional levels. For all the countries the F-statistics indicate that these regressions do provide important information about the money creation process. In all cases the residuals were closely examined in order to make sure that they were white 
noise, and consequently qualified as proxies for money surprises in the estimation of the growth equation (2). Notice that while the output equation was estimated for 1965-80, the money creation equations were estimated for 1963-80. This was done in order to allow for the inclusion of lagged money surprises in the real output growth equation.

Equations equivalent to (2) were also estimated for alternative definitions of nominal liquidity (high-powered money, domestic credit and M1). Surprises series obtained as residuals of these equations were also used in the estimation of the real output equations. Broadly speaking, the resilts obtained under these alternative definitions of unexpected liquidity growth were very similar to those reported here. $13 /$

The following output equation was actually estimated, where $n=1, \ldots 12$ refers to the twelve countries and where $t=1965, \ldots, 1980$ :

$$
\begin{aligned}
\log y_{n, t} & =\gamma_{n} \operatorname{time}+B_{1} \log (G E / Y)_{n t} \\
& +\sum_{i=0}^{2} B_{3 i}\left[\Delta \log M-\Delta \log M^{e}\right]_{n, t-1} \\
& +\sum_{i=0}^{2} B_{3 i} \log \tau_{n, t-1}+\sum_{i=0} \beta_{4 i} \log e_{n, t-1}+v_{n}+\varepsilon_{n t}
\end{aligned}
$$

This equation differs from (2) by the inclusion of lagged values of the money surprises, the terms of trade and the real exchange rate terms. In this way the possibility of a different short-and long-run effect of these variables on real output is allowed. If, for example, devaluations only have a temporary contractionary effect $B_{41}$ will be significantly negative with the coefficient of the lagged value of e being zero or positive. $14 /$ Notice also that in the estimation of equation (3) the $\gamma$ coefflcient was allowed to differ across countries. 
Table 1: MONEY CREATION PROCESSES IN 12 DEVELOPING COUNTRIES: 1963-80 $\Delta \log M_{t}=a_{0}+a_{1} \Delta \log M_{t-1}+a_{2} \Delta \log M_{t-2}+a_{3} \Delta \log M_{t-3}+a_{4} D E H_{t}+\mu_{t}$

\begin{tabular}{|c|c|c|c|c|c|c|c|c|}
\hline Country & $\mathrm{CON}$ & $\Delta \log M_{t-1}$ & $\Delta \log M_{t-2}$ & $\Delta \log M_{t-3}$ & $\mathrm{DEH}_{t}$ & $\mathrm{R}^{2}$ & D.W. & F \\
\hline India & $\begin{array}{c}0.029 \\
(1.402)\end{array}$ & $\begin{array}{c}0.944 \\
(3.661)\end{array}$ & $\begin{array}{l}-0.454 \\
(-1.485)\end{array}$ & $\begin{array}{c}0.388 \\
(1.710)\end{array}$ & $\begin{array}{l}-0.016 \\
(-0.320)\end{array}$ & 0.792 & 1.194 & 12.37 \\
\hline Malaysia & $\begin{array}{c}0.026 \\
(1.105)\end{array}$ & $\begin{array}{c}0.648 \\
(3.057)\end{array}$ & $\begin{array}{l}-0.428 \\
(-1.728)\end{array}$ & $\begin{array}{c}0.509 \\
(2.391)\end{array}$ & $\begin{array}{c}0.037 \\
(0.902)\end{array}$ & 0.764 & 1.940 & 10.51 \\
\hline Philippines & $\begin{array}{c}0.024 \\
(0.790)\end{array}$ & $\begin{array}{c}1.214 \\
(5.282)\end{array}$ & $\begin{array}{c}-1.003 \\
(-3.270)\end{array}$ & $\begin{array}{c}0.628 \\
(2.577)\end{array}$ & $\begin{array}{c}0.020 \\
(0.882)\end{array}$ & 0.700 & 1.960 & 7.59 \\
\hline Sri Lanka & $\begin{array}{c}0.015 \\
(0.647)\end{array}$ & $\begin{array}{c}0.991 \\
(2.673)\end{array}$ & $\begin{array}{l}-0.558 \\
(-1.466)\end{array}$ & $\begin{array}{c}0.162 \\
(0.350)\end{array}$ & $\begin{array}{c}0.044 \\
(0.872)\end{array}$ & 0.801 & 2.334 & 13.04 \\
\hline Thailand & $\begin{array}{c}0.031 \\
(1.430)\end{array}$ & $\begin{array}{c}1.410 \\
(6.836)\end{array}$ & $\begin{array}{l}-1.210 \\
(-4.023)\end{array}$ & $\begin{array}{c}0.579 \\
(2.344)\end{array}$ & $\begin{array}{c}0.025 \\
(0.803)\end{array}$ & 0.828 & 1.710 & 15.00 \\
\hline Greece & $\begin{array}{c}0.101 \\
(2.936)\end{array}$ & $\begin{array}{c}0.712 \\
(2.971)\end{array}$ & $\begin{array}{l}-0.655 \\
(-2.445)\end{array}$ & $\begin{array}{c}0.106 \\
(0.468)\end{array}$ & $\begin{array}{c}0.250 \\
(2.980)\end{array}$ & 0.799 & 2.101 & 12.95 \\
\hline Israel & $\begin{array}{l}-0.073 \\
(-1.627)\end{array}$ & $\begin{array}{c}0.789 \\
(3.618)\end{array}$ & $\begin{array}{c}0.038 \\
(0.132)\end{array}$ & $\begin{array}{c}0.472 \\
(1.488)\end{array}$ & $\begin{array}{c}0.017 \\
(1.825)\end{array}$ & 0.945 & 2.020 & 55.47 \\
\hline Brazil & $\begin{array}{c}0.172 \\
(1.949)\end{array}$ & $\begin{array}{c}0.943 \\
(3.710)\end{array}$ & $\begin{array}{c}-0.577 \\
(-1.708)\end{array}$ & $\begin{array}{c}0.127 \\
(0.484)\end{array}$ & $\begin{array}{c}0.164 \\
(1.951)\end{array}$ & 0.651 & 1.828 & 6.06 \\
\hline Colombia & $\begin{array}{l}-0.029 \\
(-0.768)\end{array}$ & $\begin{array}{c}0.842 \\
(4.381)\end{array}$ & $\begin{array}{l}-0.504 \\
(-2.202)\end{array}$ & $\begin{array}{c}0.783 \\
(4.344)\end{array}$ & $\begin{array}{c}0.175 \\
(1.981)\end{array}$ & 0.781 & 2.246 & 11.58 \\
\hline El Salvador & $\begin{array}{c}0.042 \\
(1.429)\end{array}$ & $\begin{array}{c}1.041 \\
(2.961)\end{array}$ & $\begin{array}{l}-0.602 \\
(-1.586)\end{array}$ & $\begin{array}{c}0.214 \\
(0.842)\end{array}$ & $\begin{array}{l}-0.021 \\
(-0.185)\end{array}$ & 0.585 & 1.697 & 4.58 \\
\hline South Africa & $\begin{array}{l}0.080 \\
(2.134)\end{array}$ & $\begin{array}{c}0.779 \\
(2.803)\end{array}$ & $\begin{array}{c}-0.659 \\
(-1.879)\end{array}$ & $\begin{array}{c}0.025 \\
(0.088)\end{array}$ & $\begin{array}{c}0.023 \\
(0.663)\end{array}$ & 0.429 & 1.779 & 2.44 \\
\hline rugoslavia & $\begin{array}{c}0.034 \\
(0.612)\end{array}$ & $\begin{array}{c}0.607 \\
(3.300)\end{array}$ & $\begin{array}{l}-0.359 \\
(-1.957)\end{array}$ & $\begin{array}{c}0.572 \\
(3.174)\end{array}$ & $\begin{array}{c}0.069 \\
(0.996)\end{array}$ & 0.604 & 1.678 & 4.97 \\
\hline
\end{tabular}

Note: Numbers in parentheses refer to t-statistics, $R^{2}$ is the coefficient of determination, D.W. is the Durbin-Watson statistic and $F$ is the F-statistic for each regression. 
The results obtained from the estimation of the $\beta$ coefficients in equation (3), and of some of its variants, are presented in Table 2 . On the other hand, the country-specific r's obtained in each of these cases are given in Table 3. First, regarding Table 2, as expected, the coefficients of the money surprises are positive. Moreover, lagged money surprises turned out to be significantly positive. This result suggests that, according to the implications of the rational expectations hypothesis, unanticipated money growth has had a significant effect on these developing countries' level of real activity. Moreover, when the money surprises terms were replaced by the actual rate of growth of money the resulting coefficients were small and insignificant, confirming the idea that money surprises only affect real activity in these countries.

As can be seen from Table 2, the coefficient of (GE/Y) was significantly positive in all equations where it was included, indicating that with other things given, higher government consumption has a positive impact on output. Regarding the coefficients of $\tau$ the results show that according to previous findings [Barro (1978), Edwards (1983)], changes in the terms of trade have no perceptive effect on real output in the developing countries. $15 /$ In equations $(3.1),(3.2),(3.3)$ and $(3.4)$ a contemporaneous and a lagged real exchange rate term were included. The results obtained are quite interesting. In all cases the coefficient of the contemporaneous real exchange rate term are negative as suggested by the contractionary devaluation view; moreover, in all cases this coefficient turned out to be significantly different from zero at conventional levels ( 5 percent and/or 10 percent). Interestingly enough, the coefficient of the once lagged real exchange $r$ ate term is positive and in all cases it is significantly different from zero at the 5 percent level. 
These results provide statistical support to the view that in the short run devaluations have a contractionary effect on aggregate output. That is, they support the short-run version of the contractionary devaluation hypothesis. Also, these findings indicate that this short-run contractionary effect is later reversed, with after one year the devaluation having an expansionary influence on output. 16/ Moreover, according to these results the contemporaneous and lagged effects of the (real) devaluation cancel themselves. Indeed a formal test on the equality (with opposite sign) of these two coeficients indicates that the null hypothesis of equality cannot be rejected. This means that in the long run in these countries (real) devaluations have had no effect on output. 17 '

The equations presented in Tabie 2 were also estimated with the rate of change of the real exchange rate instead of $10 g$ e as an independent variable. The results obtained basically confirmed those reported in Table 2; in most cases the coefficient of the contemporaneous devaluation term was negative. The coefficient of the one-year lagged real devaluation was positive and in a number of the regressions significant at the conventional levels. These results, as well as the data set, are available from the author upon request.

A potential problem with the results reported in Table 2 is that the real exchange rate (RER) may not be a completely exogenous variable. In fact, it has been argued by a number of authors that higher growth will generally result in a real appreciation of the domestic currency (Balassa 1964). In order to take this potential simultaneity problem into account, equation (3) was also estimated using a two-stages least squares variance component procedure. The results obtained fully confirmed the conclusions that emerged 
Table 2: REAL OUTPUT GROWTH AND DEVALUATIONS IN 12

DEVELOPING COUNTRIES: 1965-80

\begin{tabular}{|c|c|c|c|c|}
\hline \multirow[t]{2}{*}{. } & \multicolumn{4}{|c|}{ Equation Number } \\
\hline & $(3.1)$ & $(3.2)$ & $(3.3)$ & $(3.4)$ \\
\hline$\left[\Delta \log _{t}-\Delta \log M_{t}^{e}\right]$ & $\begin{array}{c}0.102 \\
(1.146)\end{array}$ & $\begin{array}{c}0.093 \\
(1.057)\end{array}$ & $\begin{array}{c}0.112 \\
(1.300)\end{array}$ & $\begin{array}{c}0.083 \\
(0.913)\end{array}$ \\
\hline$\left[\Delta \log M_{t-1}-\Delta \log M_{t-1}^{e}\right]$ & $\begin{array}{l}0.210 \\
(2.331)\end{array}$ & $\begin{array}{c}0.181 \\
(1.998)\end{array}$ & $\begin{array}{c}0.222 \\
(2.473)\end{array}$ & $\begin{array}{c}0.170 \\
(1.961)\end{array}$ \\
\hline $\log (G E / y)_{t}$ & $\begin{array}{l}0.112 \\
(3.023)\end{array}$ & -- & $\begin{array}{c}0.101 \\
(2.780)\end{array}$ & -- \\
\hline $\log \mathrm{TOT}_{\mathrm{t}}$ & $\begin{array}{c}0.044 \\
(1.451)\end{array}$ & -- & -- & $\begin{array}{c}0.027 \\
(0.886)\end{array}$ \\
\hline 108 TOT $_{t-1}$ & $\begin{array}{c}0.008 \\
(-0.265)\end{array}$ & -- & -- & $\begin{array}{l}-0.009 \\
(-0.274)\end{array}$ \\
\hline $\log R_{E R}$ & $\begin{array}{l}-0.083 \\
(-2.103)\end{array}$ & $\begin{array}{l}-0.067 \\
(-1.682)\end{array}$ & $\begin{array}{l}-0.077 \\
(-1.966)\end{array}$ & $\begin{array}{l}-0.070 \\
(-1.738)\end{array}$ \\
\hline $\log R_{t-1}$ & $\begin{array}{c}0.069 \\
(2.086)\end{array}$ & $\begin{array}{c}0.072 \\
(2.123)\end{array}$ & $\begin{array}{c}0.070 \\
(2.127)\end{array}$ & $\begin{array}{c}0.071 \\
(2.100)\end{array}$ \\
\hline$\overline{\mathrm{R}}^{2}$ & 0.998 & 0.998 & 0.998 & 0.998 \\
\hline SEE & 0.038 & 0.038 & 0.038 & 0.039 \\
\hline$N$ & 192 & 192 & 192 & 192 \\
\hline
\end{tabular}

Note: The numbers in parentheses are t-statistics. SEE is the standard error of the regression, $\bar{R}^{2}$ is the adjusted $R^{2}$, and $N$ refers to the number of observations. 
Table 3: ESTIMATES OF COUNTRY-SPECIFIC $\gamma^{\prime} \mathrm{s}$

\begin{tabular}{lllll}
\hline & \multicolumn{4}{c}{ Equation Number } \\
\cline { 2 - 4 } & $(3.1)$ & $(3.2)$ & $(3.3)$ & $(3.4)$ \\
\hline Brazil & 0.081 & 0.080 & 0.081 & 0.080 \\
Colombia & 0.052 & 0.056 & 0.054 & 0.057 \\
El Salvador & 0.037 & 0.042 & 0.039 & 0.043 \\
Greece & 0.053 & 0.055 & 0.053 & 0.055 \\
India & 0.036 & 0.036 & 0.035 & 0.036 \\
Israel & 0.058 & 0.061 & 0.058 & 0.062 \\
Malaysia & 0.080 & 0.080 & 0.080 & 0.080 \\
Philippines & 0.058 & 0.056 & 0.056 & 0.057 \\
South Africa & 0.037 & 0.038 & 0.036 & 0.039 \\
Sri Lanka & 0.061 & 0.054 & 0.059 & 0.055 \\
Thailand & 0.069 & 0.069 & 0.068 & 0.069 \\
Yugoslavia & 0.057 & 0.057 & 0.057 & 0.059 \\
\hline & & & & \\
\hline
\end{tabular}

Note: The numbers in parentheses are t-statistics. SEE is the standard error of the regression, $\bar{R}^{2}$ is the adjusted $R^{2}$, and $N$ refers to the number of observations. 
from the analysis of Table 2. For example, when equation (3.1) was reestimated using the two-stages technique the following result was obtained: $18 /$

$$
\begin{aligned}
& \log y_{t m}=0.100\left[\Delta \log M_{t}-\Delta \log M_{t}^{e}\right]+0.244\left[\Delta \log M_{t-1}-\Delta \log M_{t-1}^{e}\right] \\
& \text { (1.109) (2.494) } \\
& +0.121 \log (G E / Y)_{t}-0.169 \text { lOgRER }_{t} \\
& \text { (3.129) (1.747) } \\
& +0.119 \operatorname{logRER}_{t-1}+0.050 \log \tau_{t} \\
& \text { (1.953) (1.590) } \\
& -0.008 \log _{t-1} \\
& (-0.243) \\
& \overline{R^{2}}=0.998 \\
& \mathrm{SEE}=0.038
\end{aligned}
$$

To sum up, the evidence presented here is quite favorable to the contractionary devaluation hypothesis. It indicates that once other important variables are accounted for, (real) devaluations have a significantly negative effect on real output in the short run. The regression results also indicate that in the longer run devaluations have an expansionary effect on output, as the traditional view suggests. The results reported here have been obtained using a real exchange rate index as the relevant exchange rate variable. However, equation (3) was also run replacing e by the nominal exchange rate. In that case in all regressions the coefficients of the nominal exchange rate variable were not significantly different from zero. This, of course, is not surprising since, as discussed, most modern theories of nominal devaluation recognize that for a devaluation to have an effect on real activity, it has to generate a change in relative prices. 
It is important to remember that the results reported here were obtained using annual data. It is possible that if quarterly data were used a richer pattern of dynamic response of output growth to real devaluations would be found. 19 I

\section{Concluding Remarks}

In this paper the effect of (real) exchange rate changes on real output growth have been analyzed using annual data for a group of twelve developing countries during 1965-80. Specifically this paper tried to provide some empirical content to the recent controversy on whether devaluations are contractionary or expansionary. The empirical analysis was based on the estimation of a reduced-form, real-output equation that included as RHS variables money growth surprises, government expenditure, terms of trade and real exchange rates. The results were quite favorable to the short-run contractionary devaluations hypothesis. After one year, however, the evidence suggests that real devaluations do have an expansionary effect on output growth. In the long run devaluations will have no effect on output. Since the analysis was done using annual data it is not possible to investigate what the intra-year dynamic effects of devaluations on output are. 


\section{FOOTNOTES}

1/ Most IV stabilization programs, for example, rely heavily on devaluations.

$2 /$ See, for example, the account of the effect of a devaluation in any traditional textbook Strictly speaking a nominal devaluation will result in higher output only if there is unutilized capacity. If this is not the case, the nominal devaluation will be translated into an equiproportional increase in prices, and the real exchange rate will not change. On this see Johnson (1976). In this paper, however, we concentrate on the case where nominal devaluations are actually translated into real devaluations.

3' See, for example, Taylor (1983), Katseli (1983) and Buffie (1984). See also Hanson (1983).

4/ Paradoxically, perhaps, the real balance effect is also a central element of the monetary approach to devaluations. See Frenkel and Johnson (1976).

5/ See also Gylfason and Schmidt (1983). It should be noted that most theoretical models on contractionary devaluations have used a framework without capital accumulation or growth.

6/ Also the numerous studies that have investigated the effects of IMF stabilization programs on outpit have looked at real activity behavior before and after major devaluations. See,for example, the discussion in Gylfason (1983).

If On the effect of money surprises on output in developing countries see, for example, Hanson (1980). Clements and Jonson (1979), however, have shown that under certain circumstances the excess supply term used by Khan and Knight is equivalent to using money surprises. 
8/ On empirical analyses of nominal devaluations and real devaluations see, for example, Krueger (1978) and Edwards (1985).

9/ The importance of real devaluations in the adjustment process is stressed in most modern analyses of the subject. See, for example, Dornbusch (1980). Obviously if a nominal devaluation results in an equiproportional increase in the price of nontradables, the real exchange rate will not change, and there will be no effect on production or expenditure. In fact, according to Johnson (1976), if output is at its full employment level a nominal devaluation will affect prices in an equiproportionate way, without altering the real exchange rate or outputs. The evidence presented in Cooper $(1971 a, b)$, Krueger (1978) and Edwards (1985), among others, indicates that in most major nominal devaluations the real exchange $r$ ate has also been devalued. The analysis was also performed using the nominal exchange rate in equation (2). See the discussion below.

10/ It is important to emphasize that both from an analytical and empirical perspective, $e$ and $\tau$ are different variables. This point is stressed by Williamson (1983) and Katseli (1984).

11/ See, for example, Barro (1979) and Edwards (1983).

12/ See, for example, Barro (1977), Hanson (1980) and Edwards (1983). Barro (1977) discusses the assumptions implicit in the use of residuals as proxies for money growth surprises.

13/ These results are available from the author on request.

14/ Note that some authors [i.e., McCallum (1980)] have argued that in a rational expectations setting only contemporaneous surprises should be included in the output growth equation. Barro (1977), however, has argued in $f$ avor of incorporating lagged values of unanticipated money. 
15/ Equation (4) was also estimated using the rate of change of the terms of trade instead of their level. No significant changes in the results were obtained.

16/ These results correspond exactly to what Cooper (1971b) suggested almost fifteen years ago.

17 When additional lags of RER were incorporated, their coefficient was nonsignificant.

18/ The following instruments were used: All the exogenous variables in (3.1) plus twice-lagged money surprises, terms of trade, real exchange $r$ ate; and contemporary, lagged and twice-lagged changes in domestic credit.

19/ This suggests that further studies on the effects of devaluations on real activity could goneentrite on how particular sectors (i.e., manufacturing sector and so on), for which there are quarterly data, react to (real) exchange rate changes. In some sense, however, this is not a very satisfactory way to proceed, since even if devaluations have an overall expansionary effect, they will result in output reduction in sune sectors. 


\section{DATA APPENDIX}

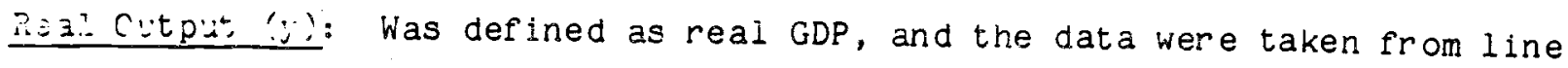
$990 . p$ of the IFS.

Nominal Money (M): A broad derinition (M2) of money was used. Average yearly values constructed from data obtained from IFS were used.

Fiscal Deficit: Data from line 80 of IFS were used.

Terms of Trade: Defined as the relative price of exports to imports; taken from the IFS supplement on international trade statistics.

Real Exchange Rate: Defined as the relative price of tradables to nontradables. This variable was proxied by a real exchange rate index constructed as the nominal exchange $r$ ate with respect to the U.S. dollar times the ratio of the U.S. WPI index to the domestic CPI index. A number of authors have recently adopted this index as the best proxy for the relative price of tradables to nontradables. In the present paper on the real exchange rate, indexes were also used as possible proxies for this relative price. The results, however, were not affected.

Government Expenditure: Defined as government current expenditure and taken from line $91 f$ of the IFS. 


\section{REFERENCES}

Balassa, Bela. "A Reappraisal of the Purchasing Power Parity Doctrine." Journal of Political Economy (1964).

Barro, Robert. "Unanticipated Money Growth and Employment in the United States." American Economic Review 67 (1977), pp. 101-15. - "Unanticipated Money, Output, and the Price Level in the United States." Journal of Political Economy 86(4) (1978). - "Money and Output in Mexico, Colombia and Brazil" in J. Behrman and J. Hanson (eds.), Short-Term Macroeconomic Policy in Lat in America. [City]: Ballinger, 1979.

Branson, William H. "Stabilization, Stagflation and Investment Incentives: The Case of Kenya 1975-80" in Sebastian Edwards and Liaquat Ahamed (eds.) Economic Adjustment and Exchange Rates in Developing Countries. Forthcoming, 1985.

Buffie, Edward. "The Macroeconomics of Trade Liberalization." Journal of International Economics 17 (August 1984), pp. 212-38.

Clements, Kenneth $W$, and Peter D. Jonson. "Unanticipated Money,

'Disequilibrium' Modelling and Rational Expectations." Economics Letters 2 (1979), pp. 303-08.

Cooper, Richard. "Currency Devaluation in Developing countries" in G. Renis (ed.) Government and Economic Development. New Haven, Conn.: Yale University Press, 1971 a.

- "Currency Depreciation in Developing Countries." Princeton

Essays in International Finance 86 (1971b).

Diaz-Alejandro, Carlos F. Exchange Rate Devaluation in a Semi-Industrialized Economy: The Experience of Argentina 1955-61. Cambridge, Mass.: MIT Press, 1965. 
Dornbusch, Rudiger. Open Economy Macroeconomics. New York: Basic Books, 1980.

Edwards, Sebastian. "The Short-Run Relation between Inflation and Growth in Latin America: Comment." American Economic Review (June 1983). - "Exchange Rates in Developing Countries." U.C.L.A.: unpublished manuscript, 1985.

Frenkel, Jacob and Harry G. Johnson. The Monetary Approach to the Balance of Payments. Toronto: University of Toronto Press, 1976.

Gylfason. T. "Credit Policy and Economic Activity in Developing Countries: An Evaluation of Stabilization Programs Supported by the IMF 1977-79." IIES Seminar Paper 268, University of Stockholm (1983). Gylfason, T. and M. Schmid. "Does Devaluation Cause Stagflation?" Canadian Journal of Economics (1983).

Gylfason, $T$, and $O$. Rislaer. "Does Devaluation Improve the Current Account." European Economic Review 25 (1984), pp. 37-64. Hanson, James. "The Short-Run Relation between Growth and Inflation in Latin America." American Economic Review 80 (1980), pp. 972-89. - "Contractionary Devaluation, Substitution in Production and Consumption, and the Role of the Labor Market." Journal of International Economics 14 (Eebruary 1983), pp. 179-89.

Johnson, Harry G. "Elasticity, Absorption, Keynesian Multiplier, Keynesian Policy and Monetary Approach to Devaluation Theory." American Economic Review $60(1976)$, pp. 448-52.

Katseli, Louka T. "Devaluation: A Critical Appraisal of the IMF's Policy Prescriptions." American Economic Review Papers and Proceedings 73(2) (May 1983) pp. 359-64. 
- "Real Exchange Rates in the 1970s" in R. Marston and J. Bilson (eds.) Exchange Rate Theory and Policy. Chicago: University of Chicago Press, 1984.

Khan, Mohsin S. and Malcolm D. Knight. "Stabilization Programs in Developing Countries: A Formal Framework." Staff Papers 28 (March 1981), pp. $1-53$.

Krueger, A.0. Liberalization Attempts and Consequences. Boston: Ballinger, 1978 .

Krugman, P. and L. Taylor. "Contractionary Effects of Devaluation." Journal of International Economics 8 (August 1978), pp. 445-56.

McCallum, B.T. "On the Observational Equivalence of Classical and Keynesian Models." Journal of Political Economy 87 (1979), pp. 399-402.

Taylor, Lance and Jeffrey Rosensweig. "Devaluation, Capital Flows and Crowding Out: A CGE Model with Portfolio Choice for Thailand." Working Paper, The World Bank, 1984.

Van Wijnbergen. Sweder. "Exchange Rate Management and Stabilization Policies in Developing Countries" in S. Edwards and L. Ahamed (eds.) Economic Adjustment and Exchange Rates in Developing Countries (forthcoming, 1985).

Williamson, John. The Exchange Rate System. Cambridge, Mass.: MIT Press for the Institute of International Economics, 1983. 